\title{
3
}

\section{The Declaration and the Postsettler Liberal State: Perspectives from Australia, New Zealand, Canada and the United States}

\section{Introduction}

Australia, Canada, New Zealand and the US have politically assertive and well-organised indigenous minority populations. In each case, their votes against the Declaration strengthened indigenous mistrust of the state. These countries objected to the Declaration on the grounds that it could threaten the territorial integrity of the state and undermine liberal democratic values. The latter objection contrasts with indigenous reservations, raised in Chapter 4, that the Declaration would impose universal liberal values on societies that were not liberal and that sought to retain their own political systems. This chapter responds to the first set of objections and shows that, in the end, its acceptance by the four states was not so much a change of position but a 'reading down' of its contents to make it more consistent with their prevailing laws, practices and institutional arrangements (Gover, 2015). Presenting an indigenous view of this acquiescence, Astenhaienton (as cited in Holder \& Corntassel, 2002) observed that 'It's easy for us [indigenous peoples] to agree. The hard part is to get governments to see the Declaration as necessary and not so threatening' (p. 141). Therefore, Wiessner (2008), who described 
the Declaration as a 'milestone of re-empowerment' (p. 1142), may have overstated the case in suggesting that the international community had, in substantive terms, arrived at a consensus on the Declaration (p. 1141).

Beyond the state, some liberals objected to the Declaration's presumption that it is sometimes just to treat people differently, yet as this chapter demonstrates, these objections reflect but one strand of liberal possibility and do not foreclose all others. The Declaration, in fact, gives indigenous aspirations the political support that comes from being able to express ideas in liberal terms in the prevailing language of international human rights.

The Declaration also affirms legal pluralism in the ways that disputes between indigenous nations and the state are resolved. Pluralism is a liberal principle that helps to make state systems of law and politics work more fairly and inclusively; it responds to self-determination's relative and relational character. However, the Declaration remains a controversial instrument, and significant objections remain from both indigenous and state perspectives. This chapter sets out and responds to state objections, and the following chapter considers indigenous arguments and shows how these arguments are responses to indigenous mistrust of the state.

\section{The Declaration and the State}

Fears that the Declaration would disrupt the territorial integrity of existing states arose from the draft document's definition of self-determination as the right of indigenous peoples to 'freely determine their political status and freely pursue their economic, social and cultural development' (UN, 2007b, annex). Explaining such fears, Kingsbury (1992) proposed that existing state indigenous policy objectives reflected a conflict between the values of justice and order. National integrity grounded in homogeneity is simple and orderly: it ensures that majority populations retain control of the political community. However, this kind of order conflicts with justice because 'legitimacy is a function of the norm-creating process and of fairness and efficacy in implementation' (Kingsbury, 1992, p. 493). In fact, and in contrast, order is also preserved by the limits that the Declaration places on self-determination's scope. For example, it cannot be 'construed as authorizing or encouraging any action which would dismember or impair, totally or in part, the territorial integrity or political unity of sovereign and independent States' (UN, 2007b, 
art. 46[1]). Thus, the Declaration does not threaten territorial integrity, but in other respects it presents a powerful challenge to state conceptions of order.

This book's argument is that justice requires distinctive and secure indigenous shares in public sovereignty. This aspiration is expressed in the Declaration in liberal democratic language; yet according to Carroll (2012), under the Declaration, 'the perceived place of indigenous nations continues to be below that of the states in which they reside' (p. 144). As an instrument of the UN, the Declaration focuses on the obligations of the state. Its foundational positions are not the political capacities of indigenous peoples. Its value lies in the constraints it places on state power and its assumption that indigenous people have the right to participate in public affairs and to maintain independent political authority.

Canada argued that the UN Working Group on Indigenous Populations, which drafted the Declaration, was unnecessary because existing laws and agreements met the just and reasonable rights of indigenous Canadians (Thompson, 2017). Canada found the Declaration 'too sweeping and open-ended' (Coates \& Holroyd, 2014, p. 7):

Canada does not want to see the traditional concept of selfdetermination used to attack the territorial integrity of a sovereign, non-colonial state. Since Canada is such a state, it does not agree that the concept of self-determination is applicable to Indigenous populations within Canada. (Department of Indian Affairs and Northern Development, as cited in Thompson, 2017, p. 30)

Positioning Canada as a 'non-colonial' state is not consistent with indigenous experience. Nor is it consistent with Gover's (2015) explanation of Canada's, Australia's, New Zealand's and the US's attempts to legitimise the postsettler state. These countries sought legitimacy by giving an assimilationist interpretation to 'the rule of law, principles of neutrality, equality and non-discrimination' (p. 346).

New Zealand argued that the Declaration was inconsistent with the Treaty of Waitangi and undermined the individual rights of universal citizenship. No evidence has emerged to support this view, nor have authoritative Maori arguments been raised to suggest any inconsistency between the Declaration and the treaty. The problem, Gover (2015) argued, is that negotiated political settlements, such as New Zealand's treaty settlements, are well advanced and sanctioned in domestic law. It was feared that the 
intrusions of international law could undermine these arrangements and prevailing political relationships, which New Zealand believed were working well:

to accede to some expressions of indigenous 'rights' in international law, even when domestic agreements give effect to norms that are consistent with such rights, because of the possibility that these rights could disrupt or undermine local bargains, allow nondiscrimination principles to be used to challenge settled claims, empower settler judiciaries to enforce or refer to those rights at the expense of domestic executive prerogatives and obligations and, in so doing, perhaps bring the discursive processes of bargaining to a premature close. (Gover, 2015, p. 347)

In Australia, Indigenous rights have traditionally been peripheral to mainstream politics. The Declaration was adopted at a time when Indigenous policy reflected the assimilationist presumptions and rhetoric of the outgoing Howard Government (1996-2007). The Liberal Party's 1988 election campaign theme song encapsulated this rhetoric: 'Son you're Australian; that's enough for anyone to be' (Brett, 2005, p. 25). The idea that there might be subnational units of identity undermined the government's view of equality grounded in sameness. The Declaration's affirmation of indigenous groups as 'peoples' who were capable of nationhood challenged this deeply held view.

Australia argued that self-determination is not a right that attaches to an undefined subgroup of a population seeking to obtain political independence' (as cited in Gover, 2015, p. 367). Canada argued that the right to self-determination should be exercised through 'negotiations between states' and the various indigenous peoples within those states as a 'necessary component of exercising the right of self-determination' (as cited in Gover, 2015, p. 367). Both countries believed that indigenous rights were not inherent but were the subject of political negotiation. Rather than self-determination, it was 'the prospective liberalism of human rights and the constitutive liberalism of state-indigenous bargaining that could be made to co-exist in the text of [the Declaration]' (Gover, 2015 , p. 361). Recognising indigenous rights relies on recognition that sovereignty is shared. 
The US argued that, rather than refer to 'indigenous peoples', the Declaration ought to address the rights of 'persons belonging to indigenous groups' (as cited in Gover, 2015, p. 365). Like the other objecting states, its position was that:

We strongly support the full participation of indigenous people in democratic decision-making processes but cannot accept the notion of a sub-national group having a 'veto' power over the legislative process. (as cited in Carroll, 2012, p. 144).

The idea that the Declaration provided a veto over certain policy decisions was shared among the four states. The veto power was read into the requirement that development activities on indigenous lands require indigenous consent (UN, 2007b, art. 10). Such power was also read into Article 26 of the Declaration, which attracted special objection because of its commitment to the indigenous right to 'the lands, territories and resources which they have traditionally owned, occupied or otherwise used or acquired' (UN, 2007b). Where this aspiration could not be met, the article provided for compensation by way of 'lands, territories and reserves equal in quality, size and legal status' (art. 28[2]). The problem, as the US explained, was that 'almost the entirety of the United States was once owned, occupied or used by American Indians, Alaska Natives and Hawaiian Natives or within the ambit of the phrase' (as cited in Gover, 2015, p. 321). Therefore:

[The US could not] agree with a blanket statement that all existing legal rights of others to lands 'traditionally occupied' by indigenous persons at some much earlier time should in all cases be set aside regardless of the circumstances. (as cited in Gover, 2015, p. 371)

The four opposing states were concerned that the Declaration would require them to return land that was already alienated and transferred to private interests and that this would undermine social cohesion and public support for the principle of negotiated settlements.

Canada's position was that the Declaration 'might not fully accord with the norms and precedents that have been established through judicial decisions and negotiations on land claims and self-government' (Canadian Human Rights Commission, as cited in Boyer, 2014, p. 12). However, the Declaration's focus is broad. Although it implies an unavoidable relationship between rights and policy outcomes, as Coates and Holroyd (2014) asserted, judicial interpretations do not suggest that the Declaration will have constitutionally disruptive effects: 
While those indigenous political thinkers and leader [sic] who argue for full Aboriginal sovereignty have found new strength in the UNDRIP, it is not likely to upset or redefine the law of the land. (p. 9)

This is partly because, in a liberal democracy, there is no such thing as 'full sovereignty'. Public sovereignty is widely dispersed and constrained by its relative and relational character. Sovereignty is constantly reconfigured and reshaped.

New Zealand and Canada feared that the Declaration would give indigenous individuals preferential access to education (Gover, 2015). However, rights to language and culture, which are essential constituents of education, only make sense as group rights-one cannot speak to oneself. Indigenous rights are distinctive because human rights can only be exercised in context. Prior occupancy and (usually violent) displacement contribute to that context, which is why Schulte-Tenckhoff (2012) is wrong to have argued that the:

culturalization of indigenous rights ... stresses cultural identity and distinctiveness over historical and legal-political aspects, such as the effects of colonialism [such that] the recognition of cultural rights comes at the price of the right of self-determination understood as a group right. (p. 67)

Culture is a group right; it is also a political right - a right that provides all others with their source and context.

The four UN member states who voted against the Declaration were also concerned that the recognition of collective land rights 'could constitute racial discrimination against non-indigenous persons' (Gover, 2015, p. 369). Their objections were not to collective rights per se but that these rights may carry benefits not available to other citizens (Gover, 2015). However, indigeneity is not concerned with rights or privileges over other citizens. Instead, it differentiates rights to make them contextually relevant. Rights to indigenous languages, cultures and resources carry no meaning for other people. Indigeneity means that indigenous rights belong in a distinctive form. The relationship between land and religious freedom is an example of that distinctiveness.

Land's spiritual dimension occurs alongside its economic purpose. The two purposes are not ordinarily in conflict for indigenous peoples. Conflicts over rights emerge when state policies privilege the economic development of non-indigenous commercial interests over the spiritual 
interests of an indigenous population. In such cases, the bounds of liberal toleration are put to the test and resolving the disagreement can be a mark of society's acceptance of religious freedom.

There is also a relationship between participation in environmental decision-making and opportunities for good health, which Black and McBean (2016) argued creates a case for 'the decolonization of environmental decision making' (p. 1). There is a well-understood causal relationship between 'socio-economic and environmental decisions' (p.1), and indigenous knowledge in environmental protection can have important policy significance. In this sense, indigenous participation is a 'need' as much as it is a 'right' (p. 1).

\section{'Soft' Law}

Ultimately, the Declaration was acceptable to the dissenting states as an instrument of 'soft' law-as a document that would not disrupt the territorial integrity of the state. However, 'soft' law can 'harden' (Villeneuve, 2016). It may be incorporated into domestic legislation and influence judicial interpretations of existing law. It can also influence the form and context of subsequent binding instruments. For example, the Canadian Federal Court has found the Declaration a persuasive instrument (Boyer, 2014, p. 13). International law can then 'substantiate' traditional rights (Gupta, Hildering \& Misiedjan, 2014, p. 26).

According to Gover (2015), the Declaration is not 'a suitable basis for the development of a binding treaty or of rules of customary international law' (p. 355). In light of this, in 2016, Australia's position was that:

Some principles in [the Declaration] remain unsettled in international law, particularly those relating to self-determination and free, prior and informed consent. Consistent with the principles of [the Declaration] ... Australia recognises the importance of engaging in good faith consultation with Indigenous peoples in relation to decisions that affect them. Australia argues that free, prior and informed consent does not include a right of veto. (Charge D’Affaires, Australian Permanent Mission, 2016, p. 1)

Canada reversed its initial opposition to the Declaration because it came to interpret the document as a 'non-legally binding [one] that does not reflect customary international law nor change Canadian 
laws' (Canadian Human Rights Commission, as cited in Cultural Survival, n.d., para. 6). One might suggest, then, that Ottawa's initial fears 'were overblown' (Thompson, 2017, p. 33) and that the country's refusal to support the Declaration was 'incongruous' with its previous policy positions (Belanger, 2010, p. 7). New Zealand's stance was similarly inconsistent with its gradual developments towards Maori selfdetermination, at least since the Treaty of Waitangi Act 1975 (NZ), which established the Waitangi Tribunal as a judicial body to hear allegations of Crown breaches of the treaty. In the Canadian and New Zealand cases, it is important to acknowledge that their objections to the Declaration, followed by their conditional support, 'does not negate [their] former [and subsequent] recognition of Indigenous rights' (Belanger, 2010, p. 7).

The US agreed that the Declaration was nonbinding yet continued to view it as a 'moral and political force' (as cited in Gover, 2015, p. 55). The US's revised position reflected its:

commitment to work with tribes, individuals, and communities to address the many challenges they face. The United States aspires to improve relations with indigenous peoples by looking to the principles embodied in the Declaration in its dealings with federally recognised tribes, while also working, as appropriate, with all indigenous individuals and communities in the United States.

Moreover, the United States is committed to serving as a model in the international community in promoting and protecting the collective rights of indigenous peoples as well as the human rights of all individuals. (United States of America, 2011, The Declaration and U.S. Initiatives, para. 1)

In 2012, the UN special rapporteur argued that the Declaration should:

serve as a beacon for executive, legislative and judicial decisionmakers in relation to issues concerning the indigenous peoples of the country. All such decision-making should incorporate awareness and close consideration of the Declaration's terms. (UN, 2012a, p. 19)

In the US, the Declaration followed measures such as the Native American Languages Act of 1990, which, according to the UN special rapporteur, 'reflect[ed] a significant level of dedication on the part of the Government to indigenous concerns within the self-determination policy framework' (UN, 2012a, p. 9). However, at other times, that dedication has not been apparent in a complex, contested and unsettled policy environment. 
For example, the Alaska Native Claims Settlement Act extinguished aboriginal title and hunting and fishing rights in favour of individual shares in corporations established to administer indigenous assets. Cultural rights and opportunities were traded for commercial shares (UN, 2012a) in the face of significant native Alaskan opposition. A further example concerns the conflict of political authority and values between the US and the Great Sioux Nation over the Keystone XL gas pipeline (discussed in Chapter 4).

Australia accepted a case for 'internal' self-determination, and the US acknowledged a right to 'self-governance' (Gover, 2015, p. 367). Their respective positions recognised that land rights:

by necessity, entails a degree of 'de facto' self-governance because the collective must decide on the intra-group allocation of rights among members of the group. The state must determine rules for the governance of transfer, succession and conservation of 'inter se' property rights.(Gover, 2015, p. 369)

However, the argument that self-determination is only an internal right of self-governance implies that it cannot simultaneously occur within the nation-state to give effect to differentiated liberal citizenship.

Self-government may presume an isolationist and unsustainable nationhood. It requires large and discrete population bases and politically cohesive institutions. This may be ideal for some indigenous populations, but it is often not supported by the infrastructural capacity of smaller communities. Nor is isolable self-government desirable for those who enjoy strong political, financial, personal and familial relationships outside the indigenous nation.

Rather than re-evaluate citizenship's structure to make it inclusive, Australia, Canada, New Zealand and the US indicated that they would entertain "special measures" intended to overcome indigenous disadvantage' (Gover, 2015, p. 362). However, 'special' or 'affirmative action' measures are limited in scope and effect. They are concerned with the temporary redistribution of resources to address the immediate consequences of material disadvantage. They do not consider the more significant imperative-namely, the removal of the political causes of relative disadvantage. 
States adopt special measures to achieve social equity. However, to accept these measures as just substitutes for political equality is to set aside meaningful rights of prior occupancy. This is why indigeneity is not a theory of egalitarian distributive justice. Material prosperity does not diminish an indigenous person's claim to existence as a member of a distinct people. Indeed, public policies grounded only in distributive justice are assimilationist. They require that indigenous peoples 'forgo the full normative implications of their claims and ... accept forms of assimilation into state institutions as restitution' (Woons, 2014, p. 5). To prevent settler self-interest being the framer of policy debate-which is the risk when policies that do not address political equality are favouredpolicy negotiations should 'begin with indigenous accounts of what is fair and reasonable' (p. 5).

\section{Liberal Objections to the Declaration}

There remain liberal objections to distinctive recognition. Liberals—such as the former leader of the New Zealand National and ACT parties, Don Brash, and former Australian prime minister John Howard-have maintained, often to significant public approval, that liberal egalitarianism alone assures indigenous people of their fundamental human equality. According to them, distinctive recognition is unnecessary — an illiberal privilege that is offensive to the proper recognition of other citizens (O'Sullivan, 2007).

According to Kymlicka (1995), the tension between liberal inclusivity and a liberalism concerned only with the rights of the acultural individual comes from the view that:

ethnic identity, like religion, is something [that] people should be free to express in their private life, but it is not the concern of the state to attach legal identities or disabilities to cultural membership or ethnic identity. (p. 4)

Waldron (2003) gives further theoretical expression to this argument: from his perspective, the universal rights of liberal citizenship impose a common obligation on all people to act justly to one another. This means that one must always act with the same regard for indigenous citizens as for all others. The claim to special recognition then becomes unnecessary and unjustified. 
However, historic injustices cannot so easily be superseded by a 'principle of proximity where justice is owed to all who are, as Kant puts it, "unavoidably side by side in a given territory irrespective of cultural or national affinity" (Waldron, 2003, p. 30). The present has emerged from somewhere. Justice requires attention to context. It cannot assume that history has endowed all citizens with equal contemporary political capacity. The colonial past conditions the colonial present. The present could potentially supersede the past, but there are numerous conditions that must first be met. For example, indigenous conceptions of justice enjoy a broader and more long-term focus than simply settling entitlements to land (Patton, 2005).

Relational justice is important and is only superseded when colonialism itself is superseded. It is erroneous to presume that, even though a right might be unjustly alienated, the injustice can still be extinguished with time and circumstance, and that no compensation is reasonably owed. Restitution is not, from this perspective, preliminary to the creation of ongoing just terms of association. For example, if a people's disconnection from land as a source of economic sustenance has been replaced over time by some other source, then the presumption is that the claim to the original property right may have been superseded.

There is a causal link between the alienation of indigenous land, whenever it occurred, and contemporary economic disadvantage (O'Sullivan, 2017). Restitutive justice requires measures that allow indigenous peoples to eliminate that disadvantage. In this way, restitutive justice is both preliminary to just terms of association and a condition of its continuance. As Justice Brennan noted in relation to the acquisition of Indigenous land in Australia, Indigenous people 'underwrote the development of the nation' (Mabo v Queensland [No 2], 1992, para. 82). These principles are recognised in New Zealand's Treaty of Waitangi settlements. The first significant treaty settlement, which took place in 1995, included an apology from the Crown for the Invasion of the Waikato in 1863-1864 and its 'crippling impact on the welfare, economy and development of Waikato [people]'. Further:

The Crown recognises that the lands confiscated in the Waikato have made a significant contribution to the wealth and development of New Zealand, whilst the Waikato tribe has been alienated from its lands and deprived of the benefit of its lands. (Waikato Raupatu Claims Settlements Act 1995 [NZ], s. 6.5) 
In contrast, Waldron (2004) argues that supersession is just because, 'unlike their ancestors', the descendants of the first colonists generally 'have nowhere else to go' (p. 268). However, the possibility that restitutive measures could occasion injustice to colonial descendants does not supersede indigenous claims. The possibility ought to be proven in specific circumstances and each injustice balanced against the other. Colonial descendants' rights to self-determination are relative and relational to the rights of others. They are not morally superior to the rights that indigenous peoples claim. Indeed, there are no cases in Australia or New Zealand in which these people have been required to surrender what is justly theirs. Indigenous peoples are not asking others to go away. Therefore, the question is not which rights are superseded, but which rights justly belong to indigenous peoples, and how are they realisable in the interests of a substantive and durable self-determination?

Colonialism was the underlying aggression. Consequently, it is reasonable that it is the colonised (not the coloniser) whose claim to self-determination is the first heard. To support the inverse-in which indigenous rights are given secondary and morally lesser consideration—would be to perpetuate the colonial order.

Waldron's (2004) supersession argument is further undermined by his own concession to the ongoing significance of religious and cultural connections to land:

The claim that the lost lands form the centre of a present way of life-and remain sacred objects despite the loss—may be as credible a hundred years on as it was at the time of the dispossession. (p. 72)

Colonialism is an ongoing relational injustice. It was not a single event 'done' to indigenous peoples. It is a system of political values that rationalise political subjugation, and a system under which justice cannot occur. Its essential presumption is that indigenous peoples have no claim to self-determination. This presumption arises from Locke's (1887) theory of property, which, as noted in the introduction, holds that sovereign authority in relation to land is acquired only by working the land for agricultural production. In Australia, early British observers concluded that Australia's Indigenous peoples did not work the land in such ways and this in itself justified their displacement.

Colonialism means that political structures, relationships and values exclude some people. A human desire or will to 'do justice' to all is not a value that people will always and everywhere accept. Political conflict 
arises in situations in which there is a difference between what people consider just for themselves and what they accept as just for others. In postsettler societies, conflict arises when non-indigenous actors demand a standard of justice for themselves that they are not willing to extend to indigenous peoples.

Waldron (2004) sets aside the significance of context to justice. Moreover, like Hegtvedt (2005), he failed to account for indigenous peoples' right and responsibility to 'do justice' to themselves. 'Doing justice' requires political capacity, and liberal egalitarian equality is not the same as self-determination's substantive equality. It is from the perspective of capacity that it is best to consider what makes indigenous claims just. Only then can one 'draw attention to the rightful role of the group in understanding justice' (Waldron, 2004, p. 121) because, as Hegtvedt (2005) correctly explained:

Understanding how people perceive the boundaries of groups that are the recipient of benefits or burdens facilitates predictions of when conflict may emerge and, potentially, how individuals will respond to differences in what is perceived as just. (p. 41)

According to Waldron (2004), indigeneity's focus on 'the priority of certain entitlements' (p. 6) means that the concept is 'used to transform what would otherwise be a forward-looking discussion of social justice' (p. 8). However, indigeneity privileges the past, such as connections to land, not as an end in itself but as preliminary to understanding the present. The past gives the present social and cultural—as well as political—context, which is a necessary foundation for participating in those 'forward-looking discussion[s] of social justice' that Waldron imagines.

Significantly, and in answer to Waldron's (2004) fears, there are liberal protections ensuring that indigenous claims 'on grounds of historical priority' cannot 'repudiate and marginalise the claims of others' to create 'a very grave moral danger' of 'impervious[ness] of the needs of others' (p. 26). Instead, the human rights of others may moderate the claim to self-determination, although not to the extent of making the claim ahistorical or apolitical as Waldron's supersession thesis would suggest.

Conceptions of justice more broadly inclusive than Waldron's (2004) depend on the strength of the just terms of association that indigenous peoples enjoy within the state. Measures of that strength may include the extent to which indigenous peoples enjoy a substantive deliberative 
agency. The public recognition of language and culture is also important. Ultimately, however, it is indigenous peoples' capacity to work out for themselves what it means to be a citizen of the state that is selfdetermination's most significant measure. That capacity is a path to indigenous people leading lives that they have reason to value (Sen, 1999a).

Just terms of association depend on property rights but are not guaranteed by that recognition alone. Broader questions of the terms of indigenous belonging to the state are important and inform ideas about how indigenous peoples might express their share in public sovereignty.

Sharing public sovereignty, or being present as a decision-maker, is important because:

It belongs to the excellent legislator to see how a city, a family of human beings ... share in the good life and in the happiness that is possible for them. (Aristotle, 2010, p. 201)

Democracy retains neo-colonial possibilities, but these are the product of how societies determine democracy's functioning; they are not inherent to the concept itself. Democracy can restrain majoritarian authority, yet states still try to limit the Declaration's full potential.

Conversely, given that the Declaration's principal right is the right to selfdetermination, it follows that indigenous peoples—not states - ought to conceptualise that potential. They ought to lead political strategies for its implementation, with states examining liberal possibilities for 'a more reparative and constitutive project-the goal of properly constituting a settler body politic and completing the constitution of the settler state by acquiring indigenous consent' (Gover, 2015, p. 346).

Consent means that shared sovereignty is more than a democratic idea; it is an essential constituent of moral legitimacy. The Treaty of Waitangi explains a distinctive Maori view about the legitimacy of the nation-state. If the state's legitimacy is accepted, thought must logically be given to the position that an indigenous group ideally wishes to occupy within the state. It is democratically reasonable that all not just some citizens contribute to determining 'the conditions under which and the practices through which authority is constituted and legitimised, and what these constitutions and legitimations enable and disable' (Shaw, 2008, p. 1). 
Consent requires all citizens' critical engagement in public affairs. Inclusive democratic government ought to mean that public institutions are not discriminatory, which is why, as a matter of restitutive justice, state education systems may play an important part in language revitalisation and allow the coercive powers of state education to yield in some ways to education's transformative capacity, as the TRC (2015) proposed:

We call on the federal government to draft new Aboriginal education legislation with the full participation and informed consent of Aboriginal peoples. The new legislation would include a commitment to sufficient funding and would incorporate the following principles:

i. Providing sufficient funding to close identified educational achievement gaps within one generation.

ii. Improving education attainment levels and success rates.

iii. Developing culturally appropriate curricula.

iv. Protecting the right to Aboriginal languages, including the teaching of Aboriginal languages as credit courses.

v. Enabling parental and community responsibility, control, and accountability, similar to what parents enjoy in public school systems.

vi. Enabling parents to fully participate in the education of their children.

vii. Respecting and honouring Treaty relationships. (pp. 320-321)

The commission also noted that the relationship between education and health has particular context for Canadian First Nations people:

We call upon the federal, provincial, territorial, and Aboriginal governments to acknowledge that the current state of Aboriginal health in Canada is a direct result of previous Canadian government policies, including residential schools, and to recognize and implement the health-care rights of Aboriginal people as identified in international law, constitutional law, and under the Treaties. (TRC, 2015, p. 322)

Gunn (2017) extended these claims beyond the expectations they create of the state by arguing that the Declaration's most important legal implication is its insistence that 'rights are defined according to Indigenous peoples' own legal traditions' (p. 35). However, definition is meaningless without participation in the implementation of rights. As Gunn (2017) herself observed: 
If Canada were to begin to embrace just rights of participation, then many more decisions (including resource development decisions) would take into consideration Indigenous laws on land and resource use. (p. 36)

However, in consideration of the problems that might arise when state courts attempted to interpret indigenous laws, Gunn (2017) proposed that 'Indigenous law [might be treated] as foreign law in Canadian courts' (p. 36). Such treatment is the antithesis of self-determination. Indeed, this proposition provides a strong example of the scope of influence that is forgone if indigenous peoples choose not to be part of the state. This book's counterargument is that if there is a need for courts to interpret indigenous laws, then there is also a need for legal pluralism as a constituent of just terms of association that would include appropriately qualified indigenous judges and counsel.

\section{Plurality}

Legal pluralism (rather than separation) reflects self-determination's character as a relative and relational power. Recognising legal pluralism requires:

that matters unfold through dialogue, as each source of legal and political authority must be persuaded to act, since ex hypothesi no one source of authority enjoys binding authority over all others. (Christie, 2017, pp. 49-50)

Benhabib (1996) argued that democracy works better when there is cultural contestation in public institutions and in civil society. She further claimed that 'constitutional and legal pluralism' (p. ix) can be defended as long as these institutions are impartial.

Legal pluralism requires indigenous access to a politically meaningful sovereignty. However, political and institutional arrangements are always preceded by ideologies - that is, by collective values that, among other considerations, make judgements about people's relative worth and thus the relative capacities they ought to enjoy as citizens. The Declaration requires inclusive public institutions; it may also require transforming the state. It is an important tool for analysing the moral legitimacy of state policies and their underlying values. However, state institutions need not provide the only proper repositories of the people's sovereignty according 
to an 'ideology of legal centralism' (Duthu, 2013, p. 3). Instead, there is scope for plurality with indigenous civil society contributing as it does to public service delivery in health, education and other social services.

Alfred (2005) is correct to have argued, with reference to the past, that sovereignty was 'an exclusionary concept rooted in adversarial and coercive Western notions of power' (p. 59). However, sovereignty's contemporary character depends on how it is interpreted as a relative and relational concept. It is not dependent on indigenous peoples matching 'the awesome coercive force of the state' (p. 59), as Alfred feared, but on indigenous peoples sharing in the political authority of the state. This may occur through indigenous leadership in the development and delivery of state functions to give cultural focus and independence to the delivery of public services such as schooling and health care.

The Declaration's capacity to influence these matters is a product of prevailing ideas about relationships between state power and indigenous self-determination across jurisdictions. For example, the UN special rapporteur proposed that the US Congress consider affirming the Declaration as 'the policy of the United States' (UN, 2012a, p. 22). However, in not outlining exactly what this meant in legal and practical policy terms, the rapporteur left open the possibility for locally contextualised interpretations of the right to self-determination (UN, 2012a).

In New Zealand, the Declaration affirms the Treaty of Waitangi. It is consistent with Maori accounts of self-determination but, like the treaty, is 'a tool, not a panacea' (Beatty, 2014, p. 49), yet the comparison remains instructive, as Maori have used the Declaration to strengthen treaty claims. The treaty has not become secondary to the Declaration, nor has the Declaration narrowed its scope. Instead, the Declaration establishes principles from which new policy ideas may emerge.

In Australia, the rights that the Declaration asserts extend native title's significance and lend authority to broader claims of citizenship. Religious freedom is a further right that the Declaration upholds. This right adds context and purpose to land claims. It is also important because it was in defence of religious freedom that liberalism developed as a political theory. 
According to Coates and Holroyd (2014), the Declaration has 'had [a] profound impact on Canadian politics' (p. 5). Indeed, they described it as 'one of the most significant international political achievements of this generation' (p. 5). However, questions remain about how the Declaration's full adoption and implementation would appear in a liberal society.

The Declaration has helped to normalise indigenous claims in Canada; however, it has not had this effect in Australia, New Zealand or the US. The situation in Canada is different because 'Canada has historically demonstrated a moral (if not always practical) commitment to key international [human rights] agreements' (Coates \& Holroyd, 2014, p. 7). For example, the Canadian Charter of Rights and Freedoms, as set out in that country's Constitution Act 1982 (Canada Act 1982 [UK] c. 11, sch. B pt. I), guarantees that:

Certain rights and freedoms shall not be construed to abrogate or derogate from any aboriginal, treaty or other rights or freedoms that pertain to the aboriginal peoples of Canada including ... any rights or freedoms that now exist by way of land claims agreements or may be so acquired. (s. 25)

Canada's Constitution Act, which is contained in the Canada Act 1982 (UK), mentions 'The existing aboriginal and treaty rights of the aboriginal peoples of Canada' (Canada Act, sch. B pt. I s. 35). This gives constitutional protection to self-government agreements (Coates \& Holroyd, 2014). The constitution protects aboriginal title and is supported by an evolving and comprehensive jurisprudence (UN, 2014). In doing so, it reflects Tully's (1995) argument that a constitution is ideally:

an intercultural dialogue in which the culturally diverse sovereign citizens of contemporary societies negotiate agreements on their forms of association over time in accordance with the three conventions of mutual recognition, consent and cultural continuity. (p. 30)

Yet there remains a 'political stalemate' between the Government of Canada and indigenous peoples over the ways in which the Declaration ought to influence domestic politics (Mitchell, 2014, p. 1). The residential schools' legacy remains strong. It is similarly difficult to remove the presumptions of the statement of the Government of Canada on Indian policy (Government of Canada, Department of Indian Affairs and Northern Development, 1969) from contemporary influence. 
On the grounds that treaties would not be relevant to exterminated peoples, the 1969 statement proposed terminating all treaties with aboriginal nations (TRC, 2015). However, under the Declaration:

1. Indigenous peoples have the right to the recognition, observance and enforcement of treaties, agreements and other constructive arrangements concluded with States or their successors and to have States honour and respect such treaties, agreements and other constructive arrangements.

2. Nothing in this Declaration may be interpreted as diminishing or eliminating the rights of indigenous peoples contained in treaties, agreements and constructive arrangements. (UN, 2007b, art. 37)

In this way, the Declaration contributes to an established indigenous politics of resistance and transformation, supporting what Corntassel (2012) has termed 'regenerating indigenous nationhood' (p. 86). Regeneration means that:

Through our everyday acts of resurgence, our ancestors along with future generations will recognize us as Indigenous to the land. And this is how our homelands will recognize us as being Indigenous to that place. (p. 99)

Resurgence is a politics of 'reconnection' (Corntassel, 2012, p. 97). It is especially significant that the Declaration recognises that the 'right to lands, territories and natural resources is the basis for [indigenous peoples'] collective survival and thus [is] inextricably linked to their right to selfdetermination' (Daes, 2008, p. 8). Corntassel's (2012) argument not only supports a politics of small-scale or grassroots resistance-understood as a willingness to exercise responsibility-but also recognition of the political capacities that responsibility requires. He asserted that:

By resisting colonial authority and demarcating their homelands via place naming and traditional management practices, these everyday acts of resurgence have promoted the regeneration of sustainable food systems in community and are transmitting these teachings and values to future generations. (p. 98) 


\section{Conclusion}

Australia, Canada, New Zealand and the US were the only UN member states to see the Declaration as a threat to their territorial integrity: a threat to the prevailing liberal order to which they wished to continue limiting indigenous access. Their objections revealed the deep conflict that exists over the nature of indigenous belonging in the postsettler liberal state. However, after 'reading down' the Declaration's legal significance, the four states came to accept it as an 'aspirational' document.

Yet, in these and other jurisdictions, indigenous peoples have used the Declaration to help frame their political aspirations and for legal and political purposes. At the same time, there are strongly argued indigenous objections to the Declaration. As the following chapter shows, these are grounded in the view that human rights, and liberal political rights more broadly, are not consistent with indigenous understandings of selfdetermination. Such objections are motivated by mistrust of the state and state positioning of indigenous peoples as antagonistic towards the public interest in matters such as mining.

The following chapter examines the creation by the state of exclusive public discourses in which indigenous 'demands' conflict with 'reasonable' public interests. These discourses exclude the indigenous from the public. Conversely, some indigenous people see no benefit in inclusion. They do not see themselves as part of the state and argue that democratic inclusion can be assimilationist, as it can involve the imposition of liberal values on nonliberal societies and can be experienced as an expression of colonial power. While this book does not accept these arguments, it acknowledges their importance because they help to explain indigenous mistrust, and, as Chapter 2 argued, being able to set aside that mistrust is an important aspiration. This is because, while indigenous nations may choose to position themselves beyond the liberal state, in doing so, they position themselves beyond the alternative liberal politics of inclusion rationalised by the Declaration. 
This text is taken from 'We Are All Here to Stay': Citizenship, Sovereignty and the UN Declaration on the Rights of Indigenous Peoples, by Dominic O'Sullivan, published 2020 by ANU Press, The Australian National University, Canberra, Australia.

doi.org/10.22459/WAAHTS.2020.03 